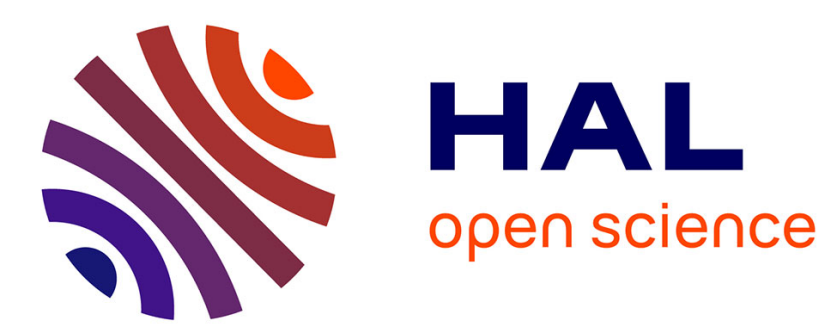

\title{
Industry Life Cycle, Knowledge Generation and Technological Networks
}

Lionel Nesta, Vincent Mangematin

\section{To cite this version:}

Lionel Nesta, Vincent Mangematin. Industry Life Cycle, Knowledge Generation and Technological Networks. F Gault, J de La Mothe. Alliances, Networks, and Partnerships in the Innovation Process, Kluwer., 23 p., 2003. hal-00424163

\section{HAL Id: hal-00424163 http://hal.grenoble-em.com/hal-00424163}

Submitted on 14 Oct 2009

HAL is a multi-disciplinary open access archive for the deposit and dissemination of scientific research documents, whether they are published or not. The documents may come from teaching and research institutions in France or abroad, or from public or private research centers.
L'archive ouverte pluridisciplinaire HAL, est destinée au dépôt et à la diffusion de documents scientifiques de niveau recherche, publiés ou non, émanant des établissements d'enseignement et de recherche français ou étrangers, des laboratoires publics ou privés. 


\section{INDUSTRY LIFE CYCLE, KNOWLEDGE GENERATION AND TECHNOLOGICAL NETWORKS}

Nesta Lionel

Mangematin Vincent

This paper examines the links between the rhythm of knowledge generation, the types of actors involved in knowledge generation and the structure of networks of collaborations in the biotech sector. The analysis departs from all biotechnology patent applications covered by Derwent Biotechnology Abstracts (DBA). In 2001, more than 96,000 patents are reported in DBA, covering 40 intellectual property authorities. First, the number of patent applications is continuously increasing, though the number of radical innovations (new technological arrangements) reaches rapidly a steady state. Second, both the number of actors and the number of collaborations follow a bell shape, thus seeming to positively correlate with the rate of technological change

First Draft.

February 2002

Do not quote without the authors' permission.

Correspondance to:

INRA

Université Pierre Mendès-France

38040 Grenoble Cedex 9

nesta@grenoble.inra.fr

vincent@grenoble.inra.fr 


\section{INTRODUCTION}

Industry Life Cycle theories have launched a vigorous research program studying the forces governing the evolution of industrial structures (Abernathy and Utterback, 1978, Utterback and Abernathy, 1975). As such, they challenge the traditional approach of industrial organisation by underlying the intrinsically changing nature of industries. Evidently, industry structures evolve on the basis of market selection. However, as technologies and competencies mobilised in a given production chain do change, firms ought to devote additional resources in learning and eventually in mastering new knowledge. Less efficient actors are not only those that fail in implementing their own production function in the short run. The may also be those that fail in modifying it in the long run (March, J. G., 1991b).

Fundamentally, life cycle theories exhibit two major phases in industry development, each being related to the state of the technological paradigm at stake (Dosi, 1982, Tushman and Anderson, 1986). While the first phase is characterised by radical and rapid technical change, the second reveals some sort of technological consolidation and stabilisation around a dominant design (Anderson and Tushman, 1990). The rising recognition of the role of knowledge in industries may well be associated with the corresponding emergence of the so-called knowledge base literature (Afuah, A. N. and Utterback, 1997a). Briefly, this fruitful research avenue emphasises the fact that firms must engage in a wide variety of learning processes (Malerba, F., 1992) not only to improve their on-going production process or innovate with new products, but also to cope with rapidly changing technological landscapes. In fact, this has quite important implications in knowledge intensive industries, for mastering a wide range of scientific and technical knowledge often proves unachievable for one isolated organisation. Instead, firms would rely on extra-organisational arrangements, supporting the view that firms are not isolated islands of production (Richardson, 1972). Empirical facts strongly support the view that firms are embedded in complex networks of alliances and collaborations. Behind the explanation of why firms establish ties lies the assumption that firms naturally benefit from the complementarity of their partners' assets and competencies (Hite and Hesterly, 2001). Several studies tend to show that profoundly interacting firms tend to achieve higher levels of performance (Powell, Koput and Smith-Doerr, 1996a). In fact, it is not the mere number of alliances that prove important. Rather, the firm's central position and the density of its network boost their innovative performance, their market value and their operating income (Afuah, A. N. and Utterback, 1997a, Baum, Calabrese and Silverman, 2000, Stuart, 2000, Stuart, Hwang and Hybels, 1999).

While the benefits drawn from networking are gradually recognised in the economic literature, much less is known regarding the temporary or permanent structure, or even presence, of networks. Put differently, ought networks to disappear with the stabilisation of industry structure, or do they express a new form of industrial organisation on its own? In the absence of clear empirical evidence, two substitutive views are confronted. Tenants of the former view posit that inter-organisational alliances 
represent a solution for firms as to cope with the instability of the technological environment. As technologies settle down, the need for external alliances becomes more blurred. Arms length contracts may well prove more efficient economically, and the underlying industrial organisation concentrates around the traditional distinction between markets and hierarchies. Eventually, networks ought to naturally evaporate. Tenants of the continuity of networks hold the opposite assumption that the very nature of technologies implies systematic ties, alliances and collaborations amongst various types of actors. Here, networks constitute a substantive form of organisational structure by itself, complementary to the traditional distinction between markets and hierarchies (Orsenigo, Pammolli and Riccaboni, 2001, Orsenigo et al., 1998). In a way, the two contradictory propositions differ in the assumption regarding the changing nature of technology. While the former pictures technology as following a specified path of non-linear but expected consolidation, the latter states that technology on its own has become intrinsically complex, profoundly rooted in the so-called knowledge base economy.

Thus, a natural way to explore both views is to tackle the evolution of a given technology and explore the actual network structure of the main actors involved in it. The objective of this paper is hence to analyse the links between the rhythm of knowledge creation, the types of actors involved in knowledge generation and the structure of networks of technological collaborations. The analysis, results, and conclusions shall be concerned with intra-paradigmatic knowledge dynamics exclusively. We define the latter in terms of rate, novelty, and conditions of knowledge combination within one of the most important technological breakthrough of the twentieth century: biotechnology. Operational measures are derived using patent statistics applied for between 1975 and 1998. The research is organised as follows. Section 2 reviews the theoretical and empirical literature as a background for the elaboration of four propositions of research. In section 3, we expose the data and method used in our fieldwork. The statistical results are commented in section 4. Two main results are exposed. First, the number of patent applications is continuously increasing, though the number of radical innovations (new technological arrangements) reaches rapidly a steady state. Second, both the number of actors and the number of collaborations follow a bell shape, thus seeming to positively correlate with the rate of technological change. Section 5 discusses and concludes the paper.

\section{LITERATURE REVIEW AND HYPOTHESES DEVELOPMENT}

\section{From exploration to exploitation}

During the past three decades, propositions concerning technological evolution have been advanced as to provide a plausible explanation of the sources of the so-called industrial life cycle. In this vein, concepts like dominant design (Utterback and Abernathy, 1975), technological trajectories and regimes (Nelson, R. R. and Winter, 1982a) technological guideposts (Sahal, 1981) and technological paradigm (Dosi, 1982) illustrate the idea that processes of knowledge generation and exploitation do not follow linear paths. Importantly, such studies of technical change insist on the idea that the 
accumulation of knowledge follows different, cyclical phases rather than the mere linear process of knowledge accumulation.

Perhaps the major feature of technological discontinuities is to introduce both new questions and their associated set of techniques that challenge pre-existing methods of doing science and/or using techniques. Two research traditions, or paradigms, can therefore compete on the basis of their unit of analysis, the set of techniques that is associated to it, leading to competing explanation of similar phenomena. Technological discontinuities occur at specific stages of knowledge development. Radical change is expressed when such discontinuities challenge and partially invalid traditional paradigms. But within the new paradigm, different methods may as well compete with one another. In other words, time for knowledge exploration and refinement is still needed in order to set standardised procedures of knowledge exploitation.

The above remarks suggest that intra-paradigmatic knowledge development follows at least two different and probably successive phases. The first one is characterised by fast knowledge creation. New procedures are explored. New technological combinations are frequently introduced in the technological system as to determine their respective effectiveness. But as new knowledge piles up, the marginal improvement is meant to decrease overtime. That is, new technologies tend to only marginally improve the existing intra-paradigmatic stock of knowledge. Here, the technological system moves onto the second stage, i.e. the establishment of a dominant design. A design is said to be dominant when its utilisation prevails over that of other knowledge (Anderson and Tushman, 1990). Importantly, the establishment of a dominant design refers to the economic production and commercialisation of technologies. Nelson and Winter (Nelson, R.R. and Winter, 1982b) define a technological regime as a particular combination of fundamental properties of technologies: opportunity and appropriability conditions, degrees of cumulativeness of technological knowledge, and characteristics of the relevant knowledge in use. Importantly, these properties go hand in hand with the development of the scientific sphere of knowledge development. It posits that the technological regime follows a similar dynamic as knowledge creation reaches an asymptote. Thus we advance:

P1: As the industry matures, the rhythm of knowledge creation is slowing down.

Taken as it stands, the above proposition must be linked to more economic phenomena. In fact, the important idea here is that technical change is directly interacting with industrial structures. New firms may well be created and might subsequently grow on the basis of their distinctive technological skills, gaining access to preferable positions on new market segments. By way of consequence, the emergence of a new paradigm may potentially destroy the traditional industrial barriers to entry, thus representing a threat to incumbents. Therefore, the development of knowledge, or say technologies, should not be thought of as given for, or provided to, incumbents of a particular industry. Rather, firms must devote efforts in implementing learning strategies as to keep up to date with relevant knowledge and techniques. Likewise, the establishment of a new dominant design calls for knowledge exploitation more than knowledge exploration. As March pointed out (March, J., 1991a), firms 
aiming at diversifying their knowledge base might be better fitted in adapting in and to an unstable environment. Yet with the stabilisation of the technological environment, exploitation strategies, i.e. the ongoing use of the firm's knowledge base (Vermeulen and Barkema, 2001) helps the organisation to refine its routines and allows it to recoup initial investments and to become profitable. Thus during the exploitation phase, firms focus on the knowledge that contributes most to its success, and filters out knowledge and routines that are less successful.

In this line of thought, one can also say that the firms' knowledge base reflects to some extend the state of the technological environment in which firms are embedded (Afuah, A. N. and Utterback, 1997a). When a dominant design appears, the choice between the different hypotheses explored reduces drastically. Thus firms might prefer to concentrate on their internal capabilities and improvements of existing capabilities, stemming from the integration of bodies of knowledge whose services has proven more profitable. Likewise, Malerba and Orsenigo (Malerba, F.; and Orsenigo, 1997) identify two patterns of innovation, namely Schumpeter Mark I and Schumpeter mark II. Schumpeter mark I is characterised by the creative destruction with technological ease of entry. In this setting, entrepreneurs and new firms play a major role in renewing industrial knowledge and by reaching higher innovative performances. Conversely, Schumpeter mark II is characterised by creative accumulation with the prevalence of large established firms and the presences of relevant barriers to entry for new innovators. Thus the authors show that both the industry structure and the nature of innovative activities are related to specific ways of accumulating knowledge. While Schumpeter Mark I relates to the first phase of intra-paradigmatic knowledge development, Schumpeter Mark II relates more to the second phase, namely that of consolidation. Importantly, the latter leads to an opposite move on the industry structure. Firms' growth, be it in terms of size or by means of acquisition or mergers, leads to an industrial shakeout (Klepper, 1997). That is, a substantial number of firms exit the industry, while survivors take stock of their past successes. This leads us to our second proposition:

P2: As the sector matures, the number of actors tends to diminish

Proposition 1 and 2 stem from the stylised facts derived from both theories and empirical analysis of the industry life cycle. Such theories provide a convincing account of how and why industries do evolve overtime, underlying the role of industrial knowledge and competencies and revealing the changing number of actors involved in the very course of market competition. Nevertheless, they tend to downplay the role of other actors that might as well prove central to relevant technological trajectories. Our main contention here is that academia is often the source of technical change, stemming from scientific developments of peculiar disciplines. As such, not only the notion of technological paradigms is similar to that of scientific paradigm (Kuhn, 1970), but both do not represent independent spheres of actors (Murray, 2001). Rather, both go closely intertwined and converse on the basis of their scientific and technical content.

Recently, there has been a substantial rise in the number of contribution revealing the economic role of academia (Brooks, 1994, Gibbons et al., 1994, Mansfield, 1995). Such contributions state that it is nowadays difficult to establish a clear frontier between academia and industries. The underlying 
reasons are multifold. First, the intensification of knowledge intensive activities has contested the traditional separation between fundamental and applied knowledge (Nelson, R., 1959). Firms mobilise both fundamental and applied knowledge in the very conduct of their productive activities. Thus, both the sequential and institutional distinction between an academic sphere initially concentrating on the creation of fundamental knowledge and an economic sphere subsequently exploiting applied knowledge can no longer hold. Second, public and private research laboratories have developed tight linked irrespective of the industry at stake. The past two decades have witnessed a considerable upsurge in research and development (R\&D) collaborations throughout market economies that transcend the traditional partition between both spheres. A third important consequence of such view is the rejection of sequential phases of knowledge development. Rather, both academia and firms play a central role of all knowledge development, from fundamental to applied knowledge and vice versa.

We do not intend to contest such well-accepted phenomena. We do also acknowledge the fundamental switch that has occurred with the move towards knowledge intensive activities and/or societies. Whether academia or firms are the sources of technological breakthroughs does not lie in our line of inquiry. But following Dasgupta and David (Dasgupta and David, 1994b), the recognition of the links between public and private laboratories should not lead to the denial of their differences with respect to their cultural background, their incentive structures, their rewards systems, etc. It follows that academic research units are supposed to be more active in knowledge creation than in innovation per se. Likewise, we might conjecture that the growing economic exploitation of given bodies of knowledge should lead to a higher involvement of private laboratories in knowledge development, that is, to a consistent rise in the number of firms involved in the economic exploitation of knowledge. Thus we might expect that the relative share of private laboratories in patenting rise overtime. We posit:

P3: As the sector matures, the role of academic research in patenting tends to diminish

The above propositions have been advanced at the theoretical level only. Actually, we shall be concerned with the analysis of the biotechnology industry, for the moment leaving apart its intrinsically heterogeneous nature. During the past thirty years, the life science industry (the seed, the agro-food, the chemical and mostly the pharmaceutical industry) has gradually awakened to the potential of biotechnology and has subsequently attempted to integrate and to master it. Of particular importance has been the emergence of new fundamental knowledge derived from molecular biology and genetic engineering. The rise and development of biotechnology was based on the project to calculate the structure and properties of biological macromolecules and cells from the physical interactions of their elementary components. Advances in this direction greatly improved the ability of researchers to rise the predictive power of the $R \& D$ activities based on the calculation of the functional properties of given molecules. Moreover, the convergence of molecular biology with information technology has brought powerful computational capabilities to biologists, allowing the storage and exploitation of very large-scale information sets. For instance in pharmaceuticals, new techniques such as high-throughput DNA sequencing, functional genomics, bioinformatics and 
proteomics are becoming fundamental tools in modelling the structure of nucleic acids and proteins, thereby providing pharmaceutical researchers with new rational tools for drug development.

Today, it is clear that the knowledge of molecular biology and genetic engineering represented a discontinuity with respect to the knowledge previously used in life sciences (Arora and Gambardella, 1994, Oliver, R., 1999). The emergence of the industry was based on the exploration of large numbers of scientific hypothesis. A growing number of actors (academic researchers, large firms and start ups) has been involved in the exploration of hypotheses. Perhaps the most striking feature related to the development of biotechnology has been the high level of firm creation since the seventies. To date, more than 3,000 dedicated biotechnology firms (DBFs) have been created throughout the world, most of which being located in the American and in the European continents (Ernst\&Young, 1998;2000). In our second proposition, we have argued that an industry shakeout should eventually be expected. Thus we now turn to another puzzling characteristic related to biotechnology, that is, inter-organisational collaborations and alliances.

Actually, biotechnology has traditionally been based on close ties between the university and the industry (Kenney, 1986). This has many justifications. First, the very nature of biotechnological knowledge blurs the previously-mentioned frontier between fundamental and applied knowledge. Discoveries in the former may boost developments in the latter while new applications may well lead to new scientific breakthroughs. As a consequence, public and private laboratories have extendedly relied on inter-organisational arrangements as to share differentiated yet complementary knowledge. A second and subtler consequence of the peculiar nature of biotechnology knowledge is that university researchers have been in the best position to exploit the potentiality of biotechnology. Indeed, many DBFs were university spin-offs, being under the scientific direction of university professors, and being actually managed by former scientists. Altogether, it is clear that university-industry relationships in biotechnology have been the rule rather than the exception.

Inter-institutional collaborations provide an extensive account of patterns of collaborations. Yet they do not exhaust it. Alliances with potential clients and other firms involved in biotechnology are needed as well (Oliver, A.L., 2001, Powell, Koput and Smith-Doerr, 1996b) generating new patterns of learning. Co-operations take different forms, from commercial, research or production agreements to joint ventures and mergers or acquisitions. Recent research on alliances and networks has stressed the value of inter-organisational relationship for assessing resources and creating competitive advantages (Dyer and Singh, 1998). The expected benefits of alliances and networks are the enrichment of the flow of knowledge amongst partners (Kogut, 1988), the access to complementary assets (Pisano, 1990) as well as access to external legitimacy and status (Baum and Oliver, 1991, Liebeskind et al., 1996). Notably, Baum et al. (Baum, Calabrese and Silverman, 2000) show that start-up's initial performance increase with the size of alliance network at founding and with the efficiency of its alliance network at founding. The authors explain how the roles of alliance vary amongst firm age and size. At founding, the variation in alliance network composition produces significant differences in 
their performance, supporting the idea that liabilities of newness and smallness result to a large extent from a lack of access to resources and stable exchange relationships.

Disappointingly, such contributions do not provide a substantial account of the changing nature of the firms' patterns of networks over time. Our contention is that the exploitation of few promising scientific results must eventually lead to corresponding changes in the structure of networks. At the level of the firm, one may well conjecture that the network structure of a given firm changes together with its size, its age, or more globally its growth. Indeed, several qualitative case studies (Mcnamara and Baden-Fuller, 1999, Steier and Greenwood, 2000) show that the composition of collaborative networks in biotechnology changes as firms grow. Commercial and financial alliances become more vital while alliances with other firms or public laboratories gradually decrease. At the level of the industry, we might equally speculate that the changing nature of the technological environment leads to different patterns of collaboration. Notably, since firms seek to appropriate knowledge and translate it into private rents, be it higher productive processes or new commercial products, the role of collaborations in innovative activities should eventually diminish as compared to earlier research phases. We propose:

P4: Collaborations and co-patenting between public and private or amongst private organisations tend to diminish as the industry matures.

\section{DATA AND METHODS}

Our study is based on Derwent Biotechnology Abstracts (DBA). DBA is a database covering all biotechnology patents applications since 1981. Today, more than 96,284 patent applications are reported in DBA, from 1965 to 2001 and covering 40 intellectual property authorities. Because two years are needed for inventory purposes, the curve drops tremendously after 1998. Therefore, the analysis shall exclusively be concerned with prior patents applications.

DBA provides several information about patent applications: the name of inventors; the patent affiliate; the date of applications; extensive summaries; key words; etc. Computer-expensive manipulations were necessary in order to translate the initial DBA information set into a workable database format. Particular attention was paid to the patent's year of application and the name of the applying organisation. Predominantly demanding was the treatment of names of organisations. Discarding missing information condenses the database to 74,905 patent applications emanating from 3,483 different names. Recurrent name misspelling was treated at length, while fusions and mergers occurring amongst firms were further taken into account. In total, 1,469 organisations were identified. Names provide valuable information about the institutional type of organisations. For instance, universities and institutes gave rise to multiple abbreviations that allowed us to easily differentiate public research organisations and private organisations, be they large firms or DBFs. A final ad hoc checking on names was performed using mainly international biotechnology directories and additional Internet resources, allowing us to geographically locate our sample of organisations. Altogether, 898 
private organisations and 571 public research organisations were identified, accounting for $78 \%$ of the overall number of patent applications recorded in the original database.

Here, it is worth stressing a number of observations. First, one should be aware of the fact that we are concentrating on a peculiar database whose coverage remains somewhat conditioned to the DBA definition of biotechnology. Whether a given patent application falls into DBA's boundaries of biotechnology is thus restricted to some subjective criteria. The important point here is that when actually analysing DBA patent applications, we are all the more concerned with a subset of an unknown exhaustive population of biotechnology patent applications. However, we are confident in the fact that the DBA coverage focuses on the core of biotechnology, while more technologically distant patent applications are discarded. Second, the modalities of actor selection imply that only relevant actors shall be included in the analysis. This induces that when analysing the evolution of the number of biotechnology actors, we are actually speaking of relevant, say important, actors, discarding marginal yet potentially essential other phenomena. Third, one should also keep in mind that DBA is a worldwide database, thus gathering different national systems of innovation together with several approval authorities. One of the most vivid manifestation of it lies in the relative share of bounded geographic areas in the total number of patent applications. Particularly, the Northern America accounts for more than one third of all recorded patent applications $(29,009)$, as Japan does $(27,927)$, while the European continent hardly amounts to one fifth $(12,932)^{1}$. While our own knowledge of biotechnology conforms to the observation of the American share, we are more dubious of the Nippon extended share.

Certainly, the previous remarks call for caution when commenting our results. The fact that only the core of biotechnology is analysed here naturally outplays additional events that, though marginal, may yield further discontinuities in the intra-paradigmatic development of biotechnological knowledge. Though aware of that, our motivation in using DBA is above all practical, conforming to a substantial number of other authors (Archibugi, 1992, Griliches, 1979;1990, Pavitt, 1988). DBA represents a unique database providing us with a chronological and systematised information set concerning both the rate of knowledge creation and the number of actors involved. Besides, DBA allows us to further describe and analyse the relationships between technical change and the underlying network structure. Concerning the analysis of technical change, we shall essentially give attention to the technological content of patent applications. Of course, there exists a multiplicity of method by which one could exploit such a large dataset (see notably (Frenken, 1998, Saviotti, 1988). While agreeing with the relevance of such methods, we focus on the technological combination of patent applications as to assess novelty in the so-called technological space. Indeed, DBA characterises each patent along thirty biotechnology-dedicated classes (see appendix 1). Theses classes were converted into a vector of 30 technology classes, taking value 1 if technology $\mathrm{i}$ occurs in patent $\mathrm{P}, 0$ otherwise. For example, if technologies $\mathrm{A}_{1}$ and $\mathrm{A}_{2}$ occur within patent $\mathrm{P}, \mathrm{P}$ can be described by the 30 dimensional vector $\mathrm{I}=\{1,1,0 \ldots 0\}$. It follows that all patent may be described along a thirty-digit string that we call a

\footnotetext{
${ }^{1}$ The remaining 5,037 patent applications come from other regions of the world.
} 
technological combination or arrangement. Within one patent, a maximum of 6 technologies may be combined, yielding a maximum number of about 768,000 possible arrangements. Since only 2,525 arrangements have been identified in DBA, the construction of the technological space exhibits farfrom-random explorative learning strategies.

\section{FIGURE 1. Sets and Subsets in DBA.}

\section{By Date, Identified Actors, and Co-Patent Applications.}

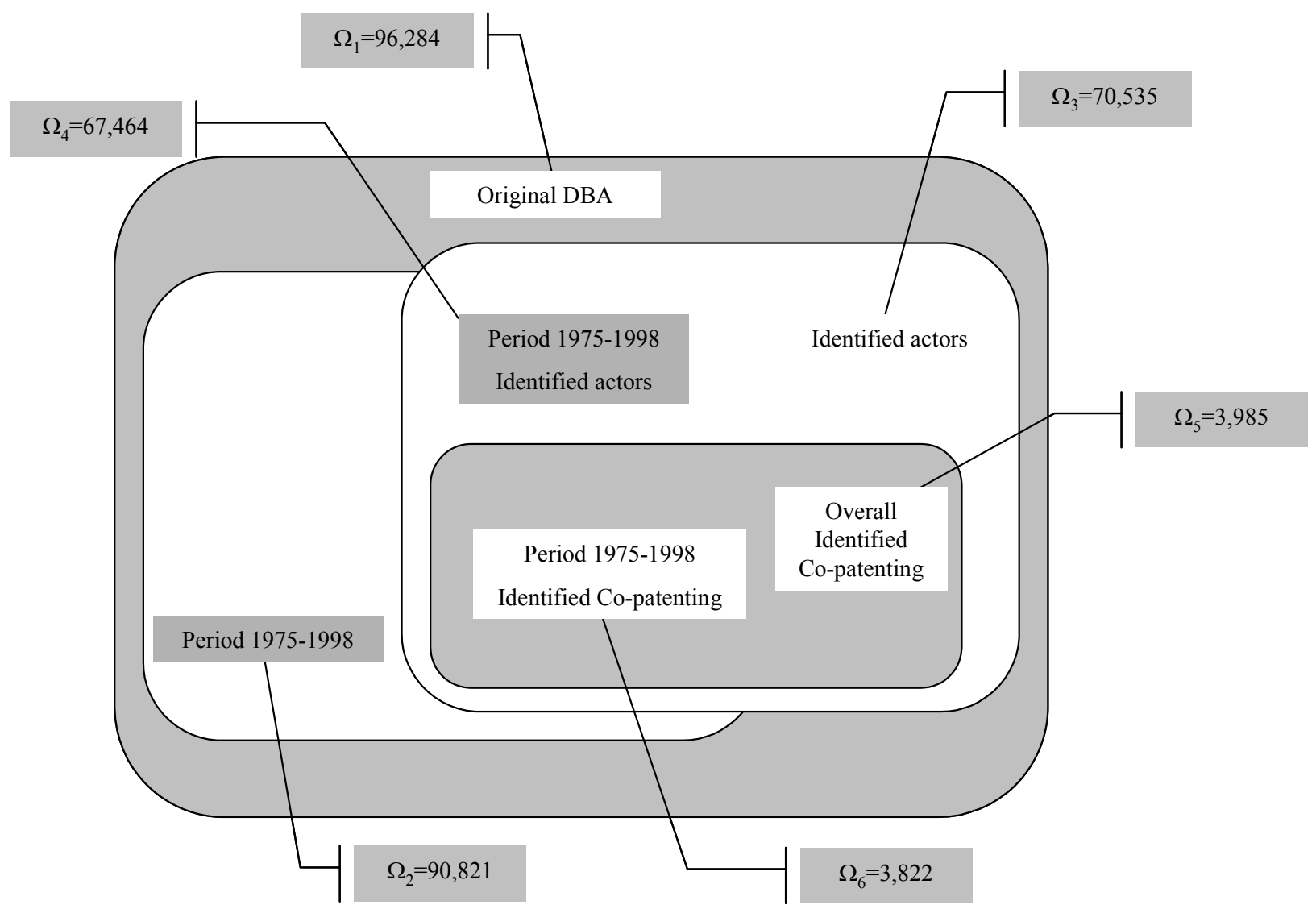

Turning to the description of network structures, co-patent applications enhance the identification of collaborations amongst actors. Clearly, this amounts to indirectly grasp actual networks of alliances and collaborations. No doubts that productive alliances, licence agreements or even development collaborations are far from systematically leading to patenting. Moreover in the DBA database, the actual content of such collaborations are undoubtedly science and technology driven. Yet this is not prohibitive, since we are essentially interested in describing patterns of scientific and technical collaborations within the intra-paradigmatic construction of the biotechnology space. Co-patenting is all the more convenient and relevant in analysing the co-evolution of knowledge and the network structure. Still, a further complication lies in the method of network description. Assessing networks is far from straightforward. For example, graph theories have proven extremely powerful in picturing networks of all sorts, including interactions among technologies or actors. Furthermore, they provide network measures of centrality and density (Burt, 1976, Freeman, C., 1991, Freeman, L., 1979) that are becoming gradually used in the economics of network literature (Orsenigo, et al., 1998). But recalling our propositions, we shall essentially depict populations of co-patenting. Consequently, each 
patent has been described by the number of actors involved together with the description of their institutional type, namely public or private. Altogether, we have identified 7,205 co-patent applications, of which 3,985 have been characterised by both the numbers and the public or private type of partners involved.

Figure 1 describes the whole process of sample construction throughout propositions 1-4. From the original 96,284 patent applications (set $\Omega_{1}$ ), the condition of relevant dates (set $\Omega_{2}$ ) and actor identification (set $\Omega_{3}$ ) led to 67,464 relevant patents (set $\Omega_{4}$ ). Over the whole period, 3,985 co-patents were identified (set $\Omega_{5}$ ), of which 3,822 belong to the $1975-1998$ period (set $\Omega_{6}$ ). Because of the very nature of propositions 1-4, no parametric statistical test seems to be eligible in the first four propositions. Since we are essentially interested in the evolution of specified indicators, a longitudinal analysis of descriptive indicators is mobilised. Table 1 both summarises our method and reveals the expected outcome according the intra-paradigmatic phase under consideration. For convenience only, the results are presented in tables rather than in graphs.

TABLE 1. Method, Indicators and Expected Outcome Through Propositions 1-4. According to the Intra-Paradigmatic Phase 1 or 2.

\begin{tabular}{|c|c|c|c|c|c|}
\hline & Indicators & Variable & Phase 1 & Phase 2 & Table \\
\hline $\mathrm{P} 1$ & $\begin{array}{l}\text { Evolution of the \# of patents } \\
\text { Evolution of the \# of new arrangements } \\
\text { Evolution of the Herfindhal index }\end{array}$ & $\begin{array}{c}\text { PAT } \\
\text { INNO } \\
\text { HERFPAT }\end{array}$ & $\begin{array}{l}\text { Increase } \\
\text { Increase } \\
\text { Decrease }\end{array}$ & $\begin{array}{l}\text { Decrease } \\
\text { Decrease } \\
\text { Increase }\end{array}$ & Table 2 \\
\hline $\mathrm{P} 2$ & $\begin{array}{l}\text { Evolution of the \# of actors } \\
\text { Evolution of the Herfindhal index }\end{array}$ & $\begin{array}{c}\text { ACTOR } \\
\text { HERFACT }\end{array}$ & $\begin{array}{l}\text { Increase } \\
\text { Decrease }\end{array}$ & $\begin{array}{l}\text { Decrease } \\
\text { Increase }\end{array}$ & Table 2 \\
\hline P3 & $\begin{array}{l}\text { Evolution of the \# of patents from public R\&D } \\
\text { Evolution of the public R\&D share in patenting }\end{array}$ & $\begin{array}{l}\text { PUBPAT } \\
\text { SPUBPAT }\end{array}$ & $\begin{array}{l}\text { Increase } \\
\text { Increase }\end{array}$ & $\begin{array}{l}\text { Decrease } \\
\text { Decrease }\end{array}$ & Table 2 \\
\hline P4 & $\begin{array}{l}\text { Evolution of global co-patenting } \\
\text { Evolution of public-private co-patenting } \\
\text { Evolution of public-public co-patenting } \\
\text { Evolution of private-private co-patenting }\end{array}$ & $\begin{array}{l}\text { COPAT } \\
\text { HYBCO } \\
\text { PUBCO } \\
\text { PRIVCO }\end{array}$ & $\begin{array}{l}\text { Increase } \\
\text { Increase } \\
\text { Increase } \\
\text { Increase }\end{array}$ & $\begin{array}{l}\text { Decrease } \\
\text { Decrease } \\
\text { Decrease } \\
\text { Decrease }\end{array}$ & Table 3 \\
\hline
\end{tabular}

In proposition 1 expecting a substantial slow down in knowledge creation, two indicators shall be mobilised, respectively the number of patents by year of application (PAT) and the number of new technological arrangements, or combinations, by year (INNO). Both shall be distinguished as they provide different types of information. The first one deals with pure knowledge creation, while the second one discriminate the newness in knowledge creation. New patents may be applied either because they consist in a radical breakthrough or because they substantially refine existing technological arrangements. Another important implication of the latter in that it allows us to measure some sort of concentration of patent applications along technological arrangements. The Herfindhal index, defined as the sum of the squared patent share for all technological arrangements, shall be used 
for this purpose (HERFPAT) ${ }^{2}$. In proposition 2, we simply count the number of actors present in DBA for each year (ACTOR). Again, this rudimentary count measure is completed by the Herfindhal index, now defined as the sum of the squared patent share for all patenting organisations (HERACT). Proposition 3 concerns the role of academia in patent applications. Two closely related measures are mobilised, the first dealing with the number of patents emanating from academia (PUBPAT), the second presenting the relative share of patent applications from public research organisations in the overall patenting activity (SPUBPAT). Finally in proposition 4, the description of network structure shall be depicted. Three types of networks are surveyed: collaborations amongst public research organisations (PUBCO), collaborations amongst private firms (PRIVCO), and hybrid networks involving both public and private organisations (HYBCO).

\section{RESULTS}

Table 2 reports the evolution of knowledge production and the actors involved in the biotech industry, associated with propositions 1, 2 and 3 respectively. Focusing on the evolution of the patenting activity between 1975 and 1998, we observe a increasing rate of patent applications. As could be expected, encouraging promises of biotechnology led to a corresponding exponential rise of patent applications (PAT). The emergence phase did not led, however, to a slow down of patent applications. Rather, the rate at which patent applications increase remains continuously quite high. In other words, knowledge creation as expressed in patent applications does not express a yet expected declining phase. This crude observation may somehow be taken with caution. The evolution of the total number of patents presents the rhythm of the global knowledge production regardless of the technological novelty held in the patent. The evolution of the variable INNO provides us with the information at need. It shows that biotechnological novelty followed a rapid growth before 1980. Reaching its highest mark in 1981, its level remains steady for the remaining of the period at stake. That is in level, the number of new technological arrangements average around 120 new combinations each year introduced in the technological landscape.

These observations lead us to conclude in the non-decreasing rate of knowledge generation, thus invalidating our first proposition. However, there exist various reasons for which we should remain careful about it. Our first reason is purely technical and reflects a database artefact. DBA introduced two new technology classes in 1992, thus boosting the variety of potential arrangements within the dataset. Though we took care in building an a-temporal nomenclature, the effect of increasing variety remained. Ignoring this artefact would lead to opposite conclusion. Second, the share of novelty (INNO) relative to patent applications (PAT) is constantly decreasing. This means that a greater part of knowledge generation is based on existing arrangements within the technological landscape. Third,

\footnotetext{
2 Other measures could well have been mobilised, namely the Gini index and the entropy measure of dispersion. All have in common to measure some sort of concentration (Herfindhal and Gini index) or its inverse, namely the dispersion (Entropy). While the magnitude of their evolution might differ from one method to the other, all displayed similar patterns of evolution.
} 
the Hinferdhal index (HERFPAT), which describes the concentration of technological arrangements, decreases until 1991 revealing the novelty of knowledge created. New technological arrangements are introduced in the technological system as scientific hypothesis are explored. However after 1991, the concentration of patents by arrangements is significantly increasing, i.e. HERFPAT rises. Consequently, the first phase corresponds to the expansion of the technological landscape by explorative learning strategies, while the second is characterised by the exploitation of existing technological arrangements. In the latter period, new technologies tend to only marginally improve the existing knowledge base of the industry within the more general framework of the established dominant design. ${ }^{3}$ Altogether, though we remain silent regarding the rhythm of knowledge generation per se, we do conclude in a more established landscape.

TABLE 2. Descriptive Statistics for Propositions 1-3.

\begin{tabular}{|c|ccc|cc|cc|}
\cline { 2 - 7 } & \multicolumn{2}{c|}{ PROPOSITION 1 } & \multicolumn{2}{c|}{ PROPOSITION 2 } & \multicolumn{2}{c|}{ PROPOSITION 3 } \\
\cline { 2 - 8 } & \multicolumn{2}{c|}{ Reference Subset $\left(\Omega_{2}\right)$} & Reference Subset $\left(\Omega_{4}\right)$ & Reference Subset $\left(\Omega_{4}\right)$ \\
\hline Year & PAT & INNO & HERFPAT & ACTOR & HERFACT & PUBPAT & SPUBPAT \\
\hline 1975 & 27 & 7 & 68.88 & 15 & 108.03 & 9 & 0.47 \\
1976 & 53 & 13 & 59.45 & 31 & 42.74 & 17 & 0.44 \\
1977 & 106 & 24 & 35.19 & 49 & 25.62 & 35 & 0.52 \\
1978 & 165 & 30 & 26.31 & 85 & 16.09 & 59 & 0.50 \\
1979 & 475 & 62 & 21.43 & 146 & 13.84 & 128 & 0.44 \\
1980 & 1192 & 105 & 18.40 & 264 & 8.66 & 297 & 0.39 \\
1981 & 2558 & 168 & 15.29 & 381 & 9.24 & 519 & 0.29 \\
1982 & 3066 & 134 & 16.07 & 443 & 8.17 & 650 & 0.29 \\
1983 & 3683 & 130 & 16.19 & 528 & 6.72 & 802 & 0.29 \\
1984 & 3862 & 132 & 17.76 & 563 & 7.21 & 833 & 0.27 \\
1985 & 3829 & 73 & 19.38 & 583 & 7.32 & 845 & 0.28 \\
1986 & 4043 & 100 & 19.43 & 641 & 5.61 & 871 & 0.26 \\
1987 & 4655 & 77 & 20.72 & 715 & 5.15 & 1122 & 0.28 \\
1988 & 4961 & 98 & 22.70 & 766 & 4.37 & 1354 & 0.32 \\
1989 & 5028 & 97 & 24.45 & 803 & 3.87 & 1333 & 0.31 \\
1990 & 4862 & 99 & 27.58 & 807 & 3.78 & 1187 & 0.29 \\
1991 & 4730 & 138 & 16.96 & 778 & 4.01 & 1106 & 0.29 \\
1992 & 5147 & 127 & 23.43 & 802 & 3.77 & 1249 & 0.30 \\
1993 & 5167 & 127 & 27.78 & 821 & 3.81 & 1392 & 0.32 \\
1994 & 5420 & 110 & 34.58 & 839 & 3.96 & 1680 & 0.37 \\
1995 & 6322 & 117 & 36.53 & 852 & 4.16 & 1965 & 0.37 \\
1996 & 6119 & 134 & 41.95 & 786 & 4.51 & 1912 & 0.39 \\
1997 & 7476 & 142 & 41.42 & 761 & 5.69 & 2026 & 0.38 \\
1998 & 7875 & 133 & 43.25 & 670 & 5.81 & 2002 & 0.40 \\
\hline
\end{tabular}

Proposition 2 is more clearly corroborated. After an exponential rise of the number of actors involved in knowledge production in biotechnology until 1990, the total of actors stabilises between 1989 to 1995 around 800 and then decreases (PAT). Thus, a gross correlation is observed between on the one

\footnotetext{
3 Indeed, a careful examination of patents (see appendix 1) shows a high concentration of patents in two central technological classes (genetic engineering and pharmaceuticals).
} 
hand, the entrance of new actors with the emergence phase, that of radical advances in biotechnology, and on the other hand the exit of actors with the establishment of an identified dominant design. The latter operates as a turning point. While it greatly reduces both product and market uncertainties, it further designs research activities around clearly perceived technological complementarities. Furthermore, as innovation becomes closer to the market, firms tend to develop product and service through internal research to maximise the potential returns to investment. The Herfindhal index (HERFACT, thus concerning actors) reaches a minimum in 1992 to subsequently increase. Knowledge production in biotechnology is more and more concentrated around given combinations and major actors, though the technological landscape is still following an expanding path.

Following Mertonian principles as guidelines (David, Mowery and Steinmuller, 1994), proposition 3 states that as innovation gets closer to the market, academic organisations become less active in knowledge creation (PUBPAT, SPUBPAT). The proposition is not verified since the share of public research organisations in patent applications is continuously increasing from 1975 to 1998. At first glance, the observed advancement of the public R\&D patenting is extremely puzzling. As pointed out by David or Callon (Callon, 1994, Dasgupta and David, 1994a), commercialisation of science ought not to be the central mission of public research. Since both technological arrangements and the number of actors reach a steady state, we would then expect public research laboratories to withdraw from the scene. Moreover in the meantime, firms are expected to take the lead of biotechnology development as they are approaching the market, hence generating turnover and profit. In fact, our intuition is as follows: this trend illustrates the commercialisation of science based on technological transfer from discovering scientists to those who will develop it commercially (Zucker, Darby and Armstrong, 2001). Here, the patenting of academically produced knowledge is one of the device used by public policies to boost technology transfer and encourage firm creation by scientists. This phenomenon, which conforms to our own knowledge of the field, may be one of the explanations of the unexpected continuous growth of the share of patent applications by public institutions.

Table 3 presents the results on the evolving technological network structure (Proposition 4). We observe a positive trend for all actors until 1995. Since then, co-patenting declines rather sharply. Focusing amongst the institutional types of partners involved in collaborations (HYBCO, PUBCO, PRIVCO) reveals that this trends concerns all actors irrespective of the organisations involved in networking. This corroborates our proposition of a sequential increase and decrease in collaborations. A finer look at the figures leads to two additional observations. First, private technological alliances constitute the core of networking until the nineties (PRIVCO). As firms seek to appropriate knowledge and translate it into private rents, the role of $R \& D$ collaborations in innovative activities is diminishing since the beginning of the nineties. This goes together with the increasing share of individual patents (except in 1998). Second, collaborations amongst public research organisations become more important in the most recent period (PUBCO). We have previously mentioned the increasing role of public research in market-oriented knowledge generation activities. Its strategy becomes closer to that of firms in term of appropriation of scientific knowledge. We thus conclude that the emergence of 
public patenting has been accompanied by a significant increase in collaborations amongst public laboratories, though their relative share in global public patent application declines.

TABLE 3. Descriptive Statistics for Propositions 4.

\begin{tabular}{|c|cc|c|ccc|c|}
\cline { 2 - 8 } \multicolumn{1}{c|}{} & \multicolumn{3}{c|}{ INDIVIDUAL PATENTS } & \multicolumn{4}{c|}{ CO-PATENTING } \\
\cline { 2 - 8 } \multicolumn{1}{c|}{} & \multicolumn{2}{c|}{ Reference Subset $\left(\Omega_{4}-\Omega_{6}\right)$} & \multicolumn{3}{c|}{ Reference Subset $\Omega_{6}$} \\
\hline YEAR & PRIV & PUB & TOTAL & HYBCO PRIVCO PUBCO & TOTAL \\
\hline 1975 & 5 & 9 & 14 & 0 & 0 & 0 & 0 \\
1976 & 20 & 15 & 35 & 0 & 1 & 1 & 2 \\
1977 & 29 & 30 & 59 & 1 & 1 & 2 & 4 \\
1978 & 56 & 48 & 104 & 1 & 0 & 5 & 6 \\
1979 & 158 & 112 & 270 & 0 & 1 & 8 & 9 \\
1980 & 444 & 271 & 715 & 6 & 6 & 10 & 22 \\
1981 & 1220 & 470 & 1690 & 18 & 17 & 15 & 50 \\
1982 & 1540 & 592 & 2132 & 8 & 14 & 25 & 47 \\
1983 & 1931 & 749 & 2680 & 19 & 25 & 16 & 60 \\
1984 & 2193 & 728 & 2921 & 30 & 29 & 36 & 95 \\
1985 & 2099 & 750 & 2849 & 37 & 33 & 28 & 98 \\
1986 & 2285 & 753 & 3038 & 28 & 64 & 44 & 136 \\
1987 & 2596 & 940 & 3536 & 59 & 75 & 55 & 189 \\
1988 & 2615 & 1129 & 3744 & 69 & 103 & 72 & 244 \\
1989 & 2685 & 1110 & 3795 & 73 & 75 & 70 & 218 \\
1990 & 2692 & 951 & 3643 & 71 & 79 & 79 & 229 \\
1991 & 2518 & 896 & 3414 & 71 & 81 & 64 & 216 \\
1992 & 2695 & 988 & 3683 & 81 & 83 & 86 & 250 \\
1993 & 2615 & 1065 & 3680 & 110 & 93 & 101 & 304 \\
1994 & 2640 & 1234 & 3874 & 116 & 75 & 149 & 340 \\
1995 & 2993 & 1498 & 4491 & 135 & 102 & 150 & 387 \\
1996 & 2728 & 1436 & 4164 & 119 & 71 & 168 & 358 \\
1997 & 3014 & 1628 & 4642 & 112 & 61 & 132 & 305 \\
1998 & 2802 & 1667 & 4469 & 85 & 50 & 118 & 253 \\
\hline TOTAL & 44573 & 19069 & 63642 & 1249 & 1139 & 1434 & 3822 \\
\hline
\end{tabular}

Our results could be summarised as follows. The evolution from emergence to maturity reveals the changing nature of technological exploration activities. Novelty is based on the creation of new arrangements reflecting the investigation of new scientific hypotheses. This phase was largely supported by the growth of scientific collaborations as revealed here. Note the substantial part of interinstitutional networks (HYBCO) in which firms and academics laboratories are involved. The transitional or maturing phase is based on arrangements within existing combinations i.e. existing but disjointed technological solutions within a given technological trajectories. In the meantime during the most recent years, networking activities seem to decrease. Thus, relying on extra-organisational partners in research activities tend to be phase-specific. That is, actors share complementary knowledge and competencies only when the technological uncertainty and the rate of novelty are high. 
When the technologies stabilise, they develop more traditional forms of organisation in research activities.

Two final remarks are worth here. First, as biotechnology appears to be a vital competence for innovation in life sciences, patents play a central role in the firms' strategies. After 1980's, the systems of intellectual property rights have gradually reckoned the economic potentialities of biotechnology. At the level of firms, stabilised and patenting has been included in firm's strategy, especially in startups' strategy. Indeed, as pointed out by Afuah and Utterback (Afuah, A. and Utterback, 1997b), patents are one of the central assets needed to succeed in the emerging (fluid) phase. Dodgson (Dodgson, 1991) and Rabinow (Rabinow, 1996) underline that one of the condition sine qua non for the creation of start-ups is the opportunity to protect their innovation. Thus the observed evolution of patent and co-patent applications reflects more profound phenomena that go far beyond the fact of mere appropriation issues. It also expresses some form of adaptive efforts of a wider set of actors, namely regulation institutions, governmental policy makers, the cultural adjustment of and in academia, not to mention other aspects regarding the demand side. At an aggregate level, technical change necessarily involves the development of new forms of organisations and institutions coordinating the local and bounded activities of a wide variety of actors.

Second, the observed declining amount of technological relationships does not necessarily deny the persistent role of collaborations. First DBA may principally reveal the first wave of biotechnology, centred on genetic sequencing and gene manipulation. And indeed, the observed evolution is well argued by the arrival of a set of stabilising research procedures and instruments, such as PCR, bioinformatics, crystallography, etc. However, recent developments in new promising areas such as genomics, proteomics, pharmaco-genomics and/or single nucleotide polymorphisms are still at infancy. We thus expect additional technological collaborations to come up in the coming years. Second recall that we are focusing on only technological collaborations expressed through copatenting. In fact, there exists a wider range of reasons for which firms, and more globally organisations, should enter into alliances (Hagedoorn, 1990). For example, the pharmaceutical industry is still witnessing a substantial number of inter-organisational ties, involving a wide variety of actors: DBFs, large pharmaceutical firms, and public laboratories. Large firms rely heavily on university ties as to improve their own knowledge base, while they call on DBFs to develop and explore new technical possibilities. Thus, our contention is that networks may reflect the changing nature of the technological landscape not in the mere number of ties, but rather in their types. In other words, networks are not dead. Their nature is simply changing together with the industry life cycle.

\section{DISCUSSION AND CONCLUSION}

This paper has analysed the evolution of network of technological collaborations during the life cycle of the industry. Based on the example of the biotech sector, it questions the network of collaborations as a new forms of organisations. Powell et al. (Powell, Koput and Smith-Doerr, 1996b) argue that in a field of rapid technological development, the locus of innovation is found within networks of 
interorganisational relationship that sustain a fluid and evolving community. Our empirical analysis refreshes the Powell's picture of networks of collaboration, in that collaborative networks are the locus of innovation during the exploration phase, while in a more stable environment, actors tend to rely more on internal learning strategies. As revealed here, collaboration is indeed the industrial organisation form, which allows the different actors to explore a large number of hypothesis and develop explorative learning in a highly uncertain environment. Such an organisation reduces risk and cost, while enhancing the sharing of knowledge, competencies and scientific results. Thus, interdependencies promote a sense of community-level mutualism (Barnett and Carroll, 1987). As the technological conditions change and as the sector matures, technological trajectories appear and firms innovate within given trajectories. The degree of novelty is reduced compared to its former level. Firms develop incremental innovation combining existing technologies that they acquire through networking in a recent past.

However, during the exploitation phase, innovation is more based on internal R\&D than in the unstable phase. On the one hand, firms already develop research capabilities and they are able to organise and perform independent research. On the other hand, as innovation is closer to the market, products and process directly compete within the market and co-operation is more difficult to develop. Networks still exist but the forms and the partnership within the network is changing. It is vital for firms to design collaborations with material and equipment providers as well as commercial networks. Whereas scientific and technological hypothesis have been explored through collaborations with divers organisations, i.e. start-ups, large firm, Dedicated biotech SMEs and academic labs, exploitation of few promising technological trajectories are developed through internal firms capabilities. The initial scientific and technological initial accumulation creates barriers to entry because of irreversible investments and because of the cumulative nature of knowledge.

Our results are coherent with the ones obtained by Nesta and Saviotti (Nesta and Saviotti, 2002) when they underline the contrasted evolution of the breadth and the coherence of the knowledge base. They reveal two different patterns of knowledge creation and two opposite types of learning. In the fluid phase, it is difficult to predict the ways by which knowledge develops. Firms have to cope with high uncertainty and explore an expanding technological landscape by diversifying their knowledge base. Though in the short run, this reduces the overall coherence of the knowledge base, it mostly enhances higher adaptive capacity to several but poorly identified technological trajectories. As technology matures, firms are likely to abandon less promising competencies to concentrate on more fruitful competencies. Importantly the focus on fewer hypotheses that leads to the dominant design creates new barriers to entry for potential incumbents because of the shift from competence destroying process in the emerging (fluid) phase to creative accumulation in the maturing (transitional) phase. In the meantime, the overall industrial configuration is changing: the market introduction of innovation leads to more rivalry among existing competitors. Winners win new markets and grow while the loosers fail. Thus size becomes more and more important in reaching a critical minimum size as to undertake costly and heavily instrumented R\&D activities. The growth of firms results from 
internal innovations and from mergers and acquisitions, which participate to the reduction of the number of actors. As bio-industries become more mature, there exists evidence of a shift towards consolidation: 198 mergers and acquisitions have been reported in the past five years, $50 \%$ of which occurred in the last two years (Ernst\&Young, 2001). The positive outcome of those mergers and acquisitions (M\&A) is likely to be the emergence of an elite of European industrial biotech leaders on which the sector could grow and compete with that of the US, which is already mature.

Public policies need to adapt to the phase of the life cycle of the industry and to prepare the entry into the next step. During the 90's in Europe, public policy have mainly focused on three objectives: (1) the building of basic research capabilities to boost the rhythm of discovery in Europe; (2) commercialisation of R\&D essentially by supporting the creation of start ups and (3) the building of common rules of the game to set up of a supporting environment with the harmonisation of IPR legislation and the creation of stock exchange for high speed growing firms. And it is quite successful. In less than ten years, the number of Europe firms is comparable to that of US ones. However, a rapid glance at the US biotech firms is in this vein extremely informative. Whereas US and Europe have a similar number of firms, European ones remain significantly smaller and weaker. First, regarding their size, European biotech SMEs represent one third of their US counterparts $(61,104$ versus 162,000 employees). Second, fewer companies have gone public (105 vs. 300). Their market capitalisation adds up to only one fifth of their US counterparts. Third, The R\&D spending and revenue streams of European firms lag far behind those of the US. 


\section{REFERENCES}

Abernathy, W.J. and Utterback, J. "Patterns of Industrial Innovation." Technology Review, 1978, 80, pp. 41-47.

Afuah, A. N. and Utterback, J. M. "Responding to Structural Industry Change: A Technological Perspective." Industrial and Corporate Change, 1997a, 6(1), pp. 183-202.

Afuah, A. and Utterback, J.M. "Responding to Structural Industry Changes: A Technological Evolution Perspective." Industrial and Corporate Change, 1997b, 6(1), pp. 183-202.

Anderson, P. and Tushman, M.L. "Technological Discontinuities and Dominant Designs: A Cyclical Models of Technological Change." Administrative Science Quarterly, 1990, 35(4), pp. 604-33.

Archibugi, D. "Patenting as an Indicator of Technological Innovation: A Review." Science and Public Policy, 1992, 19(6), pp. 357-68.

Arora, A. and Gambardella, A. "The Changing Technology of Technological Change: General and Abstract Knowledge and the Division of Innovative Labour." Research Policy, 1994, 23, pp. 523-32.

Barnett, W-P. and Carroll, G-R. "Competition and Mutualism among Early Telephone Companies." Administrative Science Quarterly, 1987, 32, pp. 400-21.

Baum, J.A.C.; Calabrese, T. and Silverman, B.S. "Don't Go It Alone: Alliance Network Composition and Startups' Performance in Canadian Biotechnology." Strategic Management Journal, 2000, 21, pp. 263-94.

Baum, J.A.C. and Oliver, C. "Institutional Linkages and Organizational Mortality." Administrative Science Quarterly, 1991, 36, pp. 187-98.

Brooks, H. "The Relationship between Science and Technology." Research Policy, 1994, 23, pp. 47786.

Burt, R. "Positions in Social Networks." Social Forces, 1976, 55, pp. 93-122.

Callon, M. "Is Science a Public Good ?" Science, Technology and Human Values, 1994, 19(4), pp. $395-425$.

Dasgupta, P. and David, P. "Toward a New Economics of Science." Research Policy, 1994a, 23(5), pp. $487-522$.

. "Toward a New Economics of Science." Research Policy, 1994b, 23(5), pp. 487-522.

David, P.; Mowery, C. and Steinmuller, E. "University-Laboratory Research Collaborations: Managing Missions in Conflict," University Goals, Institutional Mechanisms and the Industrial Transferability of Research. Stanford University:, 1994.

Dodgson, M. "The Management of Technological Learning: Lessons from a Biotechnology Company". Berlin, New York: Walter de Gruyter, 1991. 
Dosi, G. "Technological Paradigms and Technological Trajectories: A Suggested Interpretation of the Determinants and Directions of Technical Change." Research Policy, 1982, 11, pp. 147-62.

Dyer, J.H. and Singh, H. "The Relational View: Cooperative Strategy and Sources of Interorganizational Competitive Advantage." Academy of Management Review, 1998, 23, pp. $660-79$.

Ernst\&Young. "New Directions 98: The Twelth Biotechnology Industry Annual Report,", 1998, 49. . "Evolution: Ernst \& Young's Seventh Annual European Life Sciences Report 2000,", 2000, 71. . "Integration: Ernst \& Young's Eighth Annual European Life Sciences Report 2001,", 2001, 79.

Freeman, C. "Networks of Innovators: A Synthesis of Research Issues." Research Policy, 1991, 20(5), pp. 499-514.

Freeman, L. "Centrality in Social Networks: Conceptual Clarification." Social Networks, 1979, 1, pp. 215-39.

Frenken, K. "A Complexity Approach to Technological Evolution," Conférence ETIC. Strasbourg:, 1998, 1-15.

Gibbons, M.; Limoges, C.; Nowotny, H.; Schwartzman, S.; Scott, P. and Trow, M. "The New Production of Knowlegde". Stockholm: Sage Publication, 1994.

Griliches, Z. "Issues in Assessing the Contribution of Research and Development to Productivity Growth." Bell Journal of Economics, 1979, 10(1), pp. 92-116.

. "Patents Statistics as Economic Indicators: A Survey." Journal of Economic Literature, 1990, 28, pp. 1661-707.

Hagedoorn, J. "Organizational Modes of Inter-Firm Co-Operation and Technology Transfer." Technovation, 1990, 10(1), pp. 17-30.

Hite, J.M. and Hesterly, W.S. "Research Notes and Commentaries. The Evolution of Firm Networks: From Emergence to Early Growth of the Firm." Strategic Management Journal, 2001, 22, pp. 275-86.

Kenney, M. "Biotechnology: The University - Industrial Complex". New Haven \& London: Yale University Press, 1986.

Klepper, S. "Industry Life Cycles." Industrial and Corporate Change, 1997, 6(1), pp. 145-201.

Kogut, B. " Joint Ventures: Theoretical and Empirical Perspectives." Strategic Management Journal, $1988,9$.

Liebeskind, J.P.;; Oliver, A.L.; Zucker, L. and Brewer, M. "Social Networks, Learning and Flexibility: Sourcing Scientific Knowledge in Biotechnology Firms." Organization Science, 1996, 7(4), pp. 428-43.

Malerba, F. "Learning by Firms and Incremental Technical Change." The Economic Journal, 1992, 102, pp. 845-59. 
Malerba, F.; and Orsenigo, L. "Technologicla Regimes and Sectoral Patterns of Innovative Activities." Industrial and Corporate Change, 1997, 6(1), pp. 83-117.

Mansfield, E. "Academic Research Underlying Industrial Innovations: Sources, Characteristics and Financing." Review of Economics and Statistics, 1995, 75(1), pp. 55-65.

March, J. "Exploration and Exploitation in Organizational Learning." Organization Science, 1991a, 2(1), pp. 1-13.

March, J. G. "Exploration and Explotation in Organisational Learning." Organization Science, 1991b, 2(1), pp. 71-87.

McNamara, P.; and Baden-Fuller, C. "Lessons Fron the Celltech Case: Balancing Knowledge Exploration and Exploitation in Organizational Renewal." British Journal of Management, 1999, 10, pp. 291-307.

Murray, F. "Markets for Scientific Ideas: An Exploration of the Commercialization of Biomedical Science," R. Calori, EGOS 17th annual conference. Lyon (FRA):, 2001.

Nelson, R. "The Simple Economics of Basic Research." Journal of Political Economy, 1959, pp. 297306.

Nelson, R. R. and Winter, S. G. "An Evolutionary Theory of Economic Change". Havard University Press., 1982a.

Nelson, R.R. and Winter, S. "An Evolutionary Theory of Economic Change". Harvard University Press, $1982 b$.

Nesta, L. and Saviotti, P.P. "The Coherence of the Knowledge Base and the Firm's Innovative Performance. Evidence from the Us Bio-Pharmatical Industry." Submitted, 2002, pp. 30 pages.

Oliver, A.L. "Strategic Alliances and the Learning Life-Cycle of Biotechnology Firms." Organization Studies, 2001, 22(3), pp. 467-90.

Oliver, R. "The Coming Biotech Age: The Business of Bio-Materials". MacGraw-Hill, 1999.

Orsenigo, L.; Pammolli, F. and Riccaboni, M. "Technological Change and Network Dynamics. Lessons from the Pharmaceutical Industry." Research Policy, 2001, 30, pp. 485-508.

Orsenigo, L.; Pammolli, F.; Riccaboni, M.; Bonaccorsi, A. and Turchetti, G. "The Evolution of Knowledge and the Dynamics of Industry Networks." Journal of Management and Governance, 1998, 1, pp. 147-75.

Pavitt, K. "Uses and Abuses of Patent Statistics," A. F. J. van Raan, Handbook of Quantitative Studies of Science and Technologies. Elsevier Science Publishers, 1988,

Pisano, G.P. "The R\&D Boundaries of the Firm: An Empirical Analysis." Administrative Science Quarterly, 1990, 35, pp. $153-76$. 
Powell, W.W.; Koput, K.W. and Smith-Doerr, L. "Interorganisational Collaboration and the Locus of Innovation: Networks of Learning in Biotechnology." Administrative Science Quaterly, 1996a, 41, pp. 116-45.

. "Interorganisational Collaboration and the Locus of Innovation: Networks of Learning in Biotechnology." Administrative Science Quarterly, 1996b, 41, pp. 116-45.

Rabinow, P. "Making Pcr: A Story of Biotechnology". Chicago, London: University of Chicago Press, 1996.

Richardson, G.B. "The Organization of Industry." Economic Journal, 1972,, pp. 883-96.

Sahal, D. "The Farm Tractor and the Nature of Technological Innovation." Research Policy, 1981, 10, pp. 368-402.

Saviotti, P.P. "The Measurement of Change in Technological Output," A. F. J. van Raan, Handbook of Quantitative Studies of Science and Technologies. Elsevier Science Publishers, 1988, 555611.

Steier, L.; and Greenwood, R. "Entrepreneuship and the Evolution of Angel Financial Networks." Organization Studies, 2000, 21(1), pp. 163-92.

Stuart, T. "Interorganisational Alliances and the Performance of Firms: A Study of Growth and Innovation Rates in a High-Technology Industry." Strategic Management Journal, 2000, 21, pp. 791-811.

Stuart, T.; Hwang, H. and Hybels, R.C. "Inter-Organisational Endorsements and the Performance of Entrepreneurial." Administrative Science Quarterly, 1999, 44, pp. 315-49.

Tushman, M. and Anderson, P. "Technological Discontinuities and Organizational Environments." Administrative Science Quarterly, 1986, 31, pp. 439-65.

Utterback, J. M. and Abernathy, W.J. "A Dynamic Model of Process and Product Innovation." Omega, 1975, 3(6), pp. 639-56.

Vermeulen, F.; and Barkema, H. "Learning through Acquisition." Academy of Management Journal, 2001, 44(3), pp. 457-76.

Zucker, L.G.;; Darby, M.R.; and Armstrong, J. "Commercializing Knowledge: University Science, Knowledge Capture, and Firm Performance in Biotechnology," Cambridge, MA: NBER, 2001 . 


\section{Appendix 1. The DBA Database and Technology Classes}

The Derwent Biotechnology Abstracts database defines biotechnology as: "The application of biological organisms and molecules to technical and industrial processes, i.e. the application of microorganisms, animal or plant tissue cultures, enzymes, or any other cellular or sub-cellular biological system, to the production of pharmaceuticals, pesticides, chemicals, enzymes, single cell protein, energy, etc., on an industrial scale. Includes both de novo biosynthesis and specific biochemical modification of previously synthesized compounds." The following scientific items are covered in DBA: "Molecular biology and genetics, recombinant DNA techniques, cell fusion in plants, animals and microbes, animal and plant cell and tissue culture, micro-manipulation of embryos, molecular and cellular immunology, enzyme, organelle and whole cell immobilization, protein and enzyme engineering, fermentation technology and process engineering, including computerization." For each patent, the database indicates the patent holder (corporate affiliate), the year of applications and the technological areas to which the patent has been assigned. Because areas are listed, the conversion of the database into a workable format was needed. Notably, rather than having a list of the technological areas covered in a given patent, a vector of thirty technologies was assigned to all patents. This provided us with the raw material for further empirical manipulations. Descriptive statistics for each technology classes are found in table A1, covering the period 1981-1997.

TABLE A1 Descriptive Statistics for DBA Technological Occurrences

\begin{tabular}{|c|c|c|c|}
\hline Classes principales & Classes secondaires & Mean frequency & $\begin{array}{c}\text { Global Growth } \\
\text { Rate }\end{array}$ \\
\hline A-genetic-engineering-and-fermentation & $\begin{array}{l}\text { A1-Nucleic-Acid-Technology } \\
\text { A2-Fermentation }\end{array}$ & 60,5 & $+482,1$ \\
\hline B-engineering & B1-Biochemical-Engineering & 6,7 & $-38,1$ \\
\hline C-analysis & C1-Sensors-and-Analysis & 3,2 & $+42,7$ \\
\hline D-pharmaceuticals & $\begin{array}{l}\text { D1-Antibiotics } \\
\text { D2-Hormones } \\
\text { D3-Peptides-and-Proteins } \\
\text { D4-Vaccines } \\
\text { D5-Other-Pharmaceuticals } \\
\text { D6-Antibodies } \\
\text { D7-Clinical-Genetic-Techniques }\end{array}$ & 54,8 & $+555,0$ \\
\hline E-agriculture & $\begin{array}{l}\text { E1-Biological-Control-Agents } \\
\text { E2-Plant-Genetic-Engineering } \\
\text { E3-Pesticides } \\
\text { E4-In-Vitro-Propagation } \\
\text { E5-Agricultural,-Other }\end{array}$ & 9,6 & $+669,6$ \\
\hline F-food & F1-Food-and-Food-Additives & 9,6 & $-15,8$ \\
\hline G-fuels,-mining-and-metal-recovery & $\begin{array}{l}\text { G1-Biofuels-and-Solvents } \\
\text { G2-Mining-and-Metal-Recovery }\end{array}$ & 13,6 & $-28,0$ \\
\hline H-other-chemicals & $\begin{array}{l}\text { H1-Polymers } \\
\text { H2-Chiral-Compounds } \\
\text { H3-Miscellaneous-Compounds } \\
\text { H4-Polyunsaturates }\end{array}$ & 6,4 & $+185,6$ \\
\hline J-cell-culture & $\begin{array}{l}\text { J1-Animal-Cell-Culture } \\
\text { J2-Plant-Cell-Culture }\end{array}$ & 16,0 & $+229,4$ \\
\hline K-biocatalysis & $\begin{array}{l}\text { K1-Isolation-and-Characterization } \\
\text { K2-Application }\end{array}$ & 25,6 & $+75,8$ \\
\hline L-purification & L1-Downstream-Processing & 7,5 & $-77,0$ \\
\hline M-waste-disposal-and-the-environment & $\begin{array}{l}\text { M1-Industrial-Waste-Disposal } \\
\text { M2-Environmental-Biotechnology }\end{array}$ & 7,1 & $+103,0$ \\
\hline
\end{tabular}

Source: Derwent Biotechnology Abstract. 